\title{
Correcting inequality of personal incomes before income taxes and transfers: theoretical underpinnings and competition policy options
}

\author{
Friedrich L. SELL
}

\section{Universität der Bundeswehr München, Germany}

Received: 06.04.2021, Revised: 31.05.2021, Accepted: 13.06.2021

doi: http://dx.doi.org/10.29015/cerem.919

\begin{abstract}
Aim: The purpose of this paper is to bring together theory and policy of (personal) income distribution on the one hand and competition policy on the other hand.

Design / research: The methods used in this paper cover a brief model set-up, followed by a numerical model-calibration. Thereafter, we present a model simulation and proceed to a Gini decomposition. Herewith, we are able to demonstrate how market imperfections translate into a higher concentration of personal incomes.

Conclusions / findings: Our major finding is that only a rigorous competition policy is qualified to not only correct for market imperfections, but also to fight a greater inequality of personal incomes ex-ante. Originality / value of the article: This contribution provides - to our knowledge for the first time - a simultaneous explanation for stagnating, if not falling real wages and a deteriorating development of inequality of personal incomes, as measured by the Gini coefficient ex-ante. The US economy is a case study for this double observation, but many more developed economies may follow in the foreseeable future.

Limitations of the research: The implication of the research is that long before government intervenes income distribution via taxes and transfers, competition policy should correct for market imperfections and thereby reduce the inequality of personal incomes. Unfortunately, to this point, we observe a lack of meaningful macroeconomic indicators for market imperfections and hence the possibility to conduct broad econometric studies in this area of investigation.
\end{abstract}

Keywords: Market imperfections, superstar economy, Gini coefficient, competition policy.

JEL Codes: D31, D33, D42, D43, J31, L44.

Correspondence address: Friedrich L. SELL, Universität der Bundeswehr München, Germany. E-mail: friedrich.sell@unibw.de 


\section{Introduction}

The new world economy - disregarding for a moment Covid-19 - is and continues to be dominated by the forces of globalisation and digitalisation. Champions of the new digital technologies such as Amazon, Google, Apple, Facebook, Microsoft etc., make use and profit extensively of patent regulations. They help them to raise enormous revenues to the detriment of labor income and of a greater equality in the distribution of incomes between profit income on the one hand and labor income on the other hand. The argument has at least two different aspects: in the first place, it is said that monopolies which intensively reap the benefits of patent law, tend to raise the profit share vis-a-vis to the wage share (see Author et al. 2020) within the firm. This is supported by the finding that - as an indicator for a rising within-firm profit share - one observes an increasing ratio of profits per employee. Secondly, this effect will be extended over the whole economy if the portion of GDP which is generated in these monopolies rises over time. As a result, the profit (wage) share expands (shrinks) in the whole economy.

The boader context into which these observations fall, is the role of market imperferctions for the inequality of incomes. Besides the wage share and the profit share effects mentioned above, the increasing concentration of incomes, as measured by the Gini coefficient, is a further consequence of monopolies on goods markets, but also of monopsonies on factor markets. Why? Both market types tend to distort the remuneration of factors of production, such as labor income, capital income, etc. It is a distortion in the sense that monopolies should not reap the benefits of their market position beyond the (necessarily transitory) "Schumpeterian momentum". ${ }^{1} \mathrm{~A}$ more than transitory deviation of factors of production remuneration from their respective productivities is in a way "illegitimate" and stands in contrast to the convictions of a functioning market economy .

Furthermore, one may claim as a working hypothesis that the more relevant and dominant these market types become for the whole economy, the higher will be the Gini coefficient ex-ante (that is before the government intervenes with transfers

\footnotetext{
${ }^{1}$ By the "Schumpeterian momentum" it is meant that pioneering entrepreneurs are sort of allowed to temporarily enjoy the position of a monopolist provided it can be soon contested by competing imitators.
} 
and/or taxes) for the respective factor incomes. The decomposition "technique" of the Gini coefficient enables one to then aggregate the increasing concentration of labor, capital etc. compensation to the overall concentration of income(s). This opens an attractive alternative option for income (re)distribution policies: instead of waiting for the government(s) to traditionally correct the Gini coefficient ex-ante by tax and transfer instruments (which later results in a presumably lower Gini coefficient ex-post), the concentration of market incomes, as measured by the Gini coefficient ex-ante, can be directly affected by an effective and efficient competition policy. $^{2}$

It is precisely here where our contribution can help to fil a gap in research, but also in economic policy: Traditionally, theory and policy of income distribution were not concerned with questions of competition theory and policy (see, for example, Campano, Salvatore 2006). At the same time, the latter strand of economics was seldom, if at all, interested in issues of inequality (see, for example, Motta 2009). Only recently, one finds attempts to investigate barriers to entry into markets and their distributional consequences (see Colciago, Mechelli 2020), the possible links between the struggle for market shares and inequality (Hefti, Teichgräber 2021) or the impact of import competition on income quantiles of households (Helble et al. 2018).

The rest of the paper is organized as follows: In the next, second, section, we will present some stylized facts on the development of Gini coefficients and of real wages in the US economy. This is followed by a brief review of the literature related to our subject. In the third section, we theoretically develop a simple model for the factor remuneration when monopolies/monopsonies are at work and demonstrate the impact of such market imperfections on the real wage rate and the partial/overall Gini coefficients with the help of model calibration and simulation. The fourth section puts our results into the framework of the Gini decomposition approach.The fifth chapter is then dedicated to the options for competition policy to correct market

\footnotetext{
2 Traditional competition policy has not been concerned directly with distributional issues. It was led by the profound conviction that market outcomes are acceptable, as long as the market dominance of individual firms and/or attempts to hinder competition are either only transitory or can be avoided at all.
} 
imperfections and thereby reduce the concentration of personal incomes. We conclude in the sixth section.

Notice that the intention of our paper is basically a conceptual, and hence not an empirical one: the insights won here are not dependent of a specific country (sample of countres) or period(s) of observation. When we cite literature relevant to our subject, many contributions comment market imperfections in the conetxt of the US economy. But this does not imply that observations from the US economy are too "country-specific": On the contrary, especially in the field of digital platform technologies, the US development anticipates what will and does later on occur in other parts of the world economy. We want to elaborate a theoretical foundation for a new focus of competition policy and establish the direct and complementary link between goals and instruments of competition policy and, at the same time, of income distribution policy. In a sense, we plead for a Neo-Adam-Smithsonian view which expects a well functioning market economy with highly contested markets to best fulfil the requirements of an acceptable inequality of incomes.

\section{Stylized facts and a brief review of recent literature}

Figure 1 plots the Gini coefficients ${ }^{3}$ ex-ante (that is before transfers and taxes) against the calendar years, each of the 51 US states is on a separate line. Additionally, the aggregated Gini coefficient of the USA is plotted as a thick grey band. The impression one gets from Figure 1 is clear: we can observe two things. Both an upward trend - and hence an increasing concentration of personal incomes - among all the single Gini coefficients ex-ante of the 51 US states. Also, these single Gini coefficients ex-ante are converging very much since the beginning of the new millennium, though considerable convergence is already to be seen in the data long before.

\footnotetext{
${ }^{3}$ The Gini coefficient is a widely used measure of statistical dispersion or likewise of concentration intended to indicate the income inequality within a region/nation or any other sub-sample of persons. It is defined for a range between 0 (no concentration) and 1 (full concentration). It was originally developed and brought into science by the Italian statistician and sociologist Corrado Gini. See, for more details, Schira (2003: 65-75).
} 
Figure 1. Gini coefficients $(0<\mathrm{G}<1)$ for the states of the USA (1917-2015)

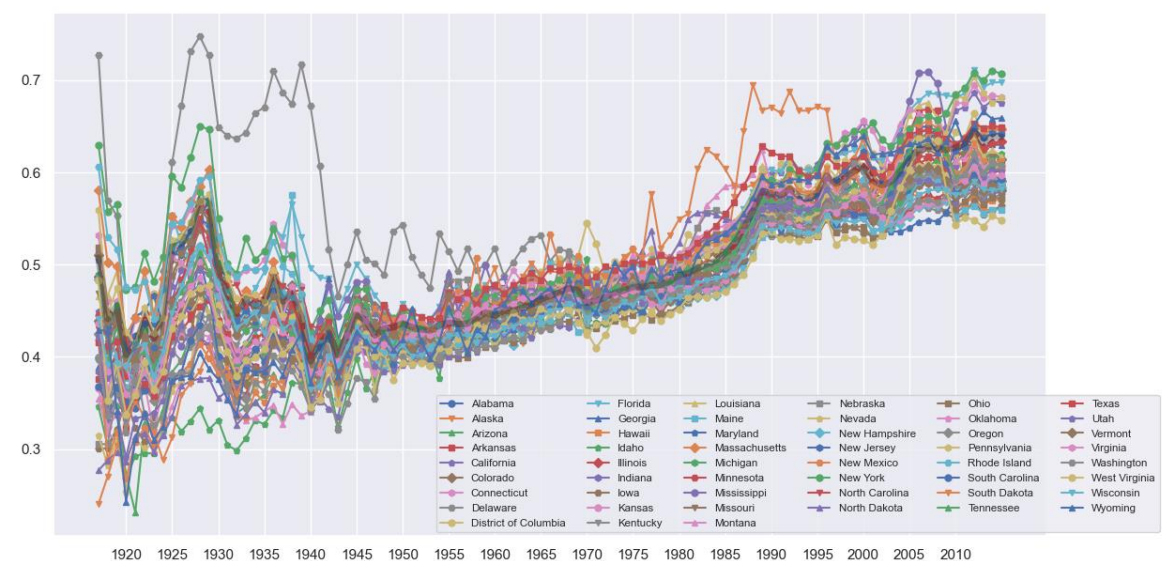

Sources: Frank (2021), own calculations and elaboration.

From Figure 2, we can also learn two things: first, that nominal average hourly wages (at current USD) rose steadily from the mid-1960s on. The five recessions (see the pink columns in Figure 2) which occurred since then could not change this picture. However, that development did not translate into real welfare gains for employees. This is the second significant observation. Real hourly wages (at constant 2019 USD) are hence almost constant in the USA since the mid-1960s. There were some moderate ups (in the 1970s) and downs (in the 1990s), but the overall impression one gets from the data is that US workers have not profited from economic growth in the US economy.

Now, the academic challenge consists in finding a theoretical framework which is capable to both explain stagnating/falling real (hourly) wages and an increasing (and possibly) converging concentration of personal incomes. ${ }^{4}$ Before we do this by means of a simple numerical model based on neoclassical tools - which is then both

\footnotetext{
${ }^{4}$ Notice that for a full explanation of the falling labour share in the USA, one needs to have also a look at GDP, at employment figures, etc. and at additional aspects of the US economy which go beyond the market imperfections we emphasize below. The network society raised by Castells (1996), but also issues such as globalisation, capital deepening, substitution of labour by capital and automation processes, etc. come into play. See, for that matter, a recent McKinsey study (2019).
} 
calibrated and simulated - let us have a short view on related literature: what do we know, what is/has been researched so far? In the few examples out of recent literature we give in the following (see below), one can find distinct and singular explanations of stagnating/falling real wages, of market imperfections (monopolies, monopsonies) and of the increase both in income inequality as in the convergence of inequality. Every single contribution brings up important aspects of our subject. But none of them, as it seems, puts them comprehensively together.

\section{Figure 2}

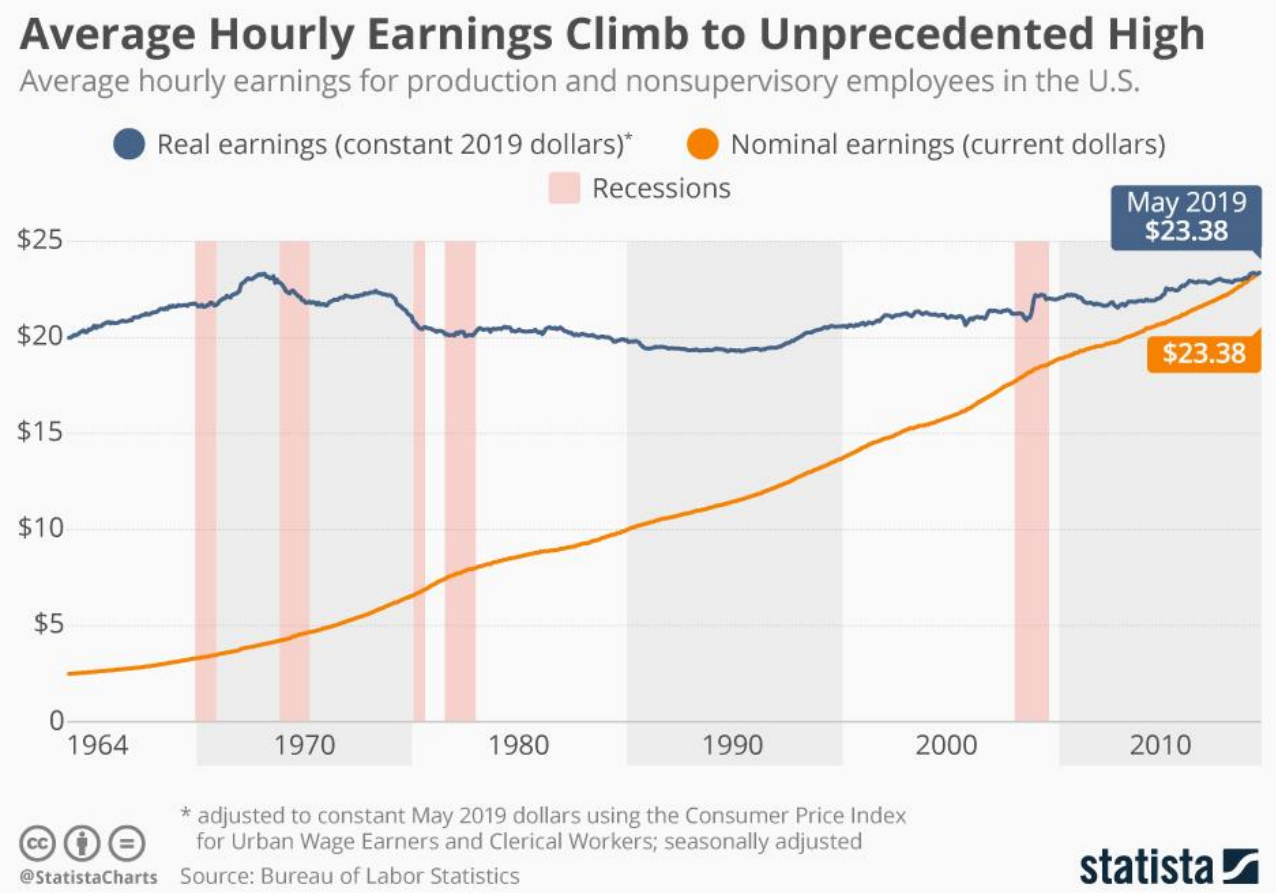

Source: Richter (2019).

Real wages in the USA

Hourly real wages, and their stagnation if not decline in the USA is a subject frequently addressed not only by academics - like Stricker (2020) and Graetz and Shapiro (2020) - but also by consulting agencies as McKinsey (2019), research units like the PEW research center (Desilver 2018) and institutional (parliamentarian) 
services as the Congressional Research service (2020): "Reports of stagnant median wages have ... therefore raised concerns among some that economic growth over the last several decades has not translated into gains for all worker groups" (Congressional Research 2020: 2).

\section{Monopolies in the US economy}

The recent "hype" (which is not too much saying) across the globe on the alleged monopoly power of US digital giants (or likewise "superstars"), such as Amazon, Google, Facebook, Apple, Microsoft etc. has raised also a new interest among economists and further scientists for market imperfections and their possible repercussions on the labor share (Author et al. 2020), on the concentration of (personal) incomes (Sell 2020) and/or the social and political consequences of their accumulated power (Moore, Tambini 2018) and control on personal data.

\section{Monopsonies in the US economy}

After a more or less short trip into the field of monopsonistic competition, labor economics seems to have steered back its focus towards monopsony itself. Many generalizing, but also country-oriented studies have been published recently. After the great recognition the investigation of Card and Krueger (1997) - whose main concern was to establish the positive employment effects that minimum wages can generate under the regime of a monopsony - received in the 1990s, nowadays, the interest centers on sectors of the US economy such as health care (Chown et al. 2019), education (Goolsbee, Syverson 2019) or even football (Makofske 2018).

\section{Increasing inequality and inequality convergence, not only in the USA}

This "double feature" needs a bit more of a paragraph: An outstanding contribution to this subject is, on a broad scale, due to Piketty and Saez (2003) and their many papers which came afterwards: on a theoretical level, the main interest of the authors is with the construction, validity and empirical relevance of the so-called Kuznets curve - an inverse- $U$ shaped function with the real per-capita income as independent and the (ex-ante) Gini coefficient as the dependent variable - for the US economy. They find a sort of "double Kuznets curve" in their data (1913-1998): 
"One could indeed argue that what has been happening since the 1970s is just a remake of the previous inverse-U curve: a new industrial revolution has taken place, thereby leading to increasing inequality, and inequality will decline again at some point, as more and more workers benefit from the innovations" (Piketty, Saez 2003: 2). At the end of the day, this finding can neither be taken as an argument in favor nor against convergence in inequality.

The paper of Lin and Huang (2011) - like an earlier study by Bao and Dhongde (2009) - is basically empirical. It makes explicitly theoretical reference, however, to the neoclassical (conditional) convergence of per-capita incomes approach in the vein of Barro and Sala-i-Martin (1999): countries or regions with similar political preferences ${ }^{5}$ and/or economic fundamentals ${ }^{6}$ tend to move towards the same timeinvariant distribution of income (Lin, Huang 2012: 154). ${ }^{7}$ The problem with this type of thinking is that "preferences" and/or "fundamentals" of an economy are often mirrored and directly affected by government consumption and/or investment. As the latter highly correlate with public taxes and transfers, Gini coefficients exante, it seems, are an inadequate means to measure inequality here.

Sell (2015) does not conduct any country-specific empirical investigations in the field of inequality convergence. However, he finds out empirically that inequality converges between the group of developing and the group of industrialized countries: while income dispersion has decreased in the first group of countries, it increased in the second group of countries. As the USA belongs to the second group of countries, this finding confirms that the steady state in the inequality of personal incomes of the USA has tended to go up (Sell 2015: 15-19).

Doran and Jordan (2015), analyze changes in the levels and in the composition of income inequality among US counties in the period from 1969 to 2009. They also decompose inequality using the Theil coefficient into between-state and within-state inequality. Their article finds that income inequality has increased in the period studied with between-state inequality decreasing and within-state inequality

\footnotetext{
${ }^{5}$ Such as for democracy, independency of key public institutions, the rule of law etc.

${ }^{6}$ Such as the degree of industrialization, stock of human capital, etc.

${ }^{7}$ Notice that this formulation literally resembles in total a phrase in Bao, Dhongde (2009: 296). When it comes to neoclassical convergence theory, it seems, as if one is assuring (only) what the other says or has said before.
} 
increasing. The authors subsequently decompose income inequality into the proportion arising from differences in productivity and employment-population ratios across counties. The results suggest that inequality arising from differentials in labor productivity has fallen over the period studied while those arising from employment-population ratio differences have increased.

Apergis et al. (2018) defend the idea of club convergence, which is the perception that specific states, sectors, regions, who share a number of important similarities (institutions, jurisdictional system, etc.), move from "disequilibrium positions to their club-specific steady state positions" (Apergis et al. 2018: 152). Studying a very long period of inequality (1929-2009), the authors come to the conclusion that a sort of mixed picture evolves, especially in the more recent past: while in the 1970s and in part of the 1980s, the hypothesis of convergence is supported, divergence dominates thereafter.

One of the most recent significant contributions to our subject stems from Sergio Rey (2018): his extensive investigation on US states, over a huge period of time (1929-2012), concludes that interpersonal inequality displayed - for the longest time - a (not inverse, but a "correct", the author) $U$ pattern (Rey 2018: 174). "By contrast, interregional income inequality between the US states has displayed a general decline up until the end of this period where convergence has slowed or even reversed" (Rey 2018: 174).

Guo and Sell $(2020,2021)$ develop a political economy equilibrium framework for personal income distribution. In the beginning, they set up a theoretical model rooted in status theory. With this concept, one may explain a certain or optimal degree of inequality in society and define a steady-state to which inequality can converge. By taking the aggregated Gini coefficient due to a collective decision process, deviations from the steady-state due to shocks are allowed. A return to equilibrium is feasible with speed compatible with the collective decision-making process. The authors then conduct an empirical analysis of personal income distribution in 28 European nations for the period before, during, and after the great recession of 2009/2010 and the Euro crisis of 2010/2015 (1995-2019). Not surprisingly, they find inequality convergence in the data. However, the speed of convergence is not the same for all countries. 
3. Profits, wages, prices, income and employment against the background of market imperfections: a calibration of monopoly cum monopsony (and of competition cum competition)

The aim of this section is to explain what the occurrence of a "double imperfection", that is both on the goods ("monopoly", one supplier only) and on the labour ("monopsony", one employer only) market implies for the remuneration of labour and capital, but also for profits, prices, employment and income achieved. To keep things simple, we concentrate on the factor of production "labour". The results achieved can be compared in theory with a "perfect world" of competition both on the goods and on the factor market. We then proceed to a numerical calibration of both models ("monopoly cum monopsony" vs. "competition cum competition") which enables us finally to conduct a simulation experiment of the distributional consequences for each scenario, as measured by the implied Gini coefficients ex ante. The idea behind this procedure is to demonstrate how dominant market positions - either on the goods ("monopoly") or on the labour market ("monopsony") - tend to deteriorate personal income distribution.

\section{Monopsony in theory}

The following equation defines the maximization problem of a monopsonist: $\pi$ stands for the profit of the firm, $p$ is the price of the output good, $w$ is the nominal wage rate, $y$ is output, which depends on labor $L$ and capital $K$ (here capital $\bar{K} \geq 0$ is a constant parameter). Hence, the monopsonist maximizes profit vis-à-vis labour input $L$ when the marginal revenues and the marginal costs of labor equate: 


$$
\begin{aligned}
& \text { (1) } \max _{L} \pi(\mathrm{L})=\max _{L}\{p y(\mathrm{~L}, \overline{\mathrm{K}})-L[w]-\mathrm{r} \overline{\mathrm{K}}\} \\
& \text { (2) } \frac{\partial \pi}{\partial L}=p \frac{\partial y}{\partial L}-\left(\frac{\partial w}{\partial L} L+w\right)=0, \text { hence } \\
& \text { (3) } p\left[1+\frac{1}{\frac{\partial L}{\frac{\partial w}{L}}: \frac{w}{L}}\right] \frac{\partial y}{\partial L}=w
\end{aligned}
$$

\section{Monopoly in theory}

The following equation defines the maximization problem of a monopolist, with the standard definition of economic variables (see above). Hence, also the monopolist maximizes profit vis-à-vis labour input $L$ when the marginal revenues and the marginal costs of labor equate:

$$
\begin{aligned}
& \text { (4) } \max _{L} \pi(\mathrm{L})=\max _{L}\{p(\mathrm{y}) \mathrm{y}(L, \bar{K})-L w-r \bar{K}\} \\
& \text { (5) } \frac{\partial \pi}{\partial L}==\frac{\partial p}{\partial y} \frac{\partial y}{\partial L} y+\frac{\partial y}{\partial L} p-w=0
\end{aligned}
$$

Hence

$$
\text { (6) } p\left[1+\frac{1}{\frac{\partial y}{\partial p}: \frac{y}{p}}\right] \frac{\partial y}{\partial L}=w
$$




\section{Monopoly cum monopsony in theory}

Integrating both solutions yields ${ }^{8}$ :

$$
\text { (7) } p\left[\frac{1+\frac{1}{\frac{\partial y}{\partial p}: \frac{y}{p}}}{1+\frac{1}{\frac{\partial L}{\partial w}: \frac{w}{L}}}\right] \frac{\partial y}{\partial L}=w
$$

In the following, we disregard from the factor Capital $(K)$ and consider all income sources in the dimension "Euro per hour".

\section{Numerical calibration of monopoly cum monopsony}

Demand function: $p=30-0.4 y^{2}$

Marginal revenue: $M R=30-1.2 y^{2}$

Labour supply: $w=5+0.9 \mathrm{~L}$

Marginal costs: $M C=5+1.8 \mathrm{~L}$

Production function: $y(L)=10 \sqrt{L}=10 L^{0.5} ; y^{2}=100 L$

Marginal Revenue: $M R=30-120 L=5+1.8 L=M C ; y^{2}=100 L=20.5$

Numerical Output: $y=4.528$

Marginal productivity of labour: $\frac{\partial y(L)}{\partial L}=11.038=0.5 \cdot \frac{1}{\sqrt{0.205}}$

Wage rate: $w=5.185$

Labour input: $L=0.205$

Price: $p=30-0.4 \times 20.5=21.799$

Real wage rate: $\frac{w}{p}=\frac{5.185}{21.799}=0.238$

${ }^{8}$ It is evident from the formula that the development of (marginal) labour productivity is a further decisive factor for the explanation of stagnating real wages (see above). This subject, however, goes well beyond the scope of this paper. The same applies to the important question whether monopolies/monopsonies are a hindering factor for the evolution of labour productivity, as long as they persist much longer than a Schumpeterian innovator would do. To test for the existence of the latter would at least require to detect significant imitators. 
Wage formula: $w=5+0.9 L=5.185=21.799 \times 11.038\left[\frac{1+\frac{1}{\eta}}{1+\frac{1}{\sigma}}\right]$

$$
5.185=240.617 \cdot\left[\frac{1+\frac{1}{\eta}}{1+\frac{1}{\sigma}}\right] ; \quad 0.022=\left[\frac{1+\frac{1}{\eta}}{1+\frac{1}{\sigma}}\right]
$$

Profits: $\pi=21.799 \times 4.528-5.185 \times 0.205=99.706-1.063=98.643$

Profits per hour: $\frac{\pi}{L}=481.185$

\section{Numerical calibration of competition cum competition}

Marginal Revenue (price): $M R=15=p$

Marginal costs (wage rate): $M C=6.50=\mathrm{w}^{9}$

Real wage rate: $\frac{w}{p}=\frac{6.5}{15}=0.433$

Production function: $(L)=10 \sqrt{L}=10 L^{0.5} ; y^{2}=100 L$

Marginal productivity of labour: $\frac{\partial y(L)}{\partial L} \cdot 15=6.50 ; \frac{\partial y(L)}{\partial L}=0.433=0.5 \frac{1}{\sqrt{L}}$; $\frac{1}{\sqrt{L}}=0.867$

Labour input: $\sqrt{L}=1.153 ; L=1.130$

Numerical Output: $y(L)=11.53$

Profits: $\pi=15 \times 11.53-6.50 \times 1.13=172.95-7.345=165.605$

Profits per hour: $\frac{\pi}{L}=146.553$

The results of the model calibration are clear: wages per hour are higher under competition cum competition (6.50 vs. 5.185), while profits per hour are higher under monopoly cum monopsony (481.185 vs. 146.553$)$. The same applies to real wages and real profits (0.433 vs. 0.238$)$.

In the Annex, we have simulated the corresponding Gini coefficients of labour income per hour, of profit income per hour and of total income per hour, separately. In Tables 1 and 2, we have calculated Gini coefficient for wages ( $€$ per hour); the wages corresponding to the different market forms are sort of stylized figures of the numbers we achieved in the model calibration ( $5 €$ vs. $6.5 €)$.

\footnotetext{
${ }^{9}$ Knowing the structural difference between the "monopoly cum monopsony" and the "competition cum competition" model enables us to choose sort of "freely" the nominal wage rate (higher) and the price level (lower) in the latter constellation.
} 
In both Tables, we suppose the existence of 10 different markets with either "monopoly cum monopsony" or with "competition" prevailing as a market form. In Table 1, the assumption is that 10 percent of the markets are organized by "monopoly cum monopsony", and $90 \%$ by competition, in Table 2 we assume an equal share $(0.5 / 0.5)$ of both market forms. When calculating the respective Gini coefficients, one gets a clear result: the Gini coefficient is strictly lower in an economy with a comparatively high share of competitive markets: $0.021<0.062$.

In Tables 3 and 4, we have calculated Gini coefficient for profits ( $€$ per hour); the profits corresponding to the different market forms are sort of stylized figures of the numbers we achieved in the model calibration (300€ per hour vs. $100 €$ per hour). In Table 3, the assumption is that 10 percent of the markets are organized by "monopoly cum monopsony", and $90 \%$ by competition. In Table $\mathbf{4}$, we assume an equal share $(0.5 / 0.5)$ of both market forms. When calculating the respective Gini coefficients, one gets a clear result: the Gini coefficient is strictly lower in an economy with a comparatively high share of competitive markets: $0.136<0.227$.

In Tables $\mathbf{5 a} / \mathbf{5 b}$ and $\mathbf{6 a / 6} \mathbf{b}$, we finally have calculated Gini coefficient for the sum of profits ( $€$ per hour) and wages ( $€$ per hour). The Gini decomposition axioms (see below) allow for that. In Tables $\mathbf{5 a} / \mathbf{5} \mathbf{b}$, the assumption is that 10 percent of the markets are organized by "monopoly cum monopsony", and $90 \%$ by competition, in Tables $6 \mathbf{6} / \mathbf{6 b}$, we assume an equal share $(0.5 / 0.5)$ of both market forms. When calculating the respective Gini coefficients, one gets a clear result: the Gini coefficient is strictly lower in an economy with a comparatively high share of competitive markets: $0.129<0.219$. 
CORRECTING INEQUALITY OF PERSONAL INCOMES BEFORE INCOME TAXES ...

Table 1. Calculation of the Gini coefficient for wages ( $€$ per hour), monopoly cum monopsony and competition $(0.1 / 0.9)$ with 10 different markets

\begin{tabular}{|c|c|c|c|}
\hline $\begin{array}{c}\text { Original } \\
\text { Distribution }\end{array}$ & $\begin{array}{c}\text { Accumulated } \\
\text { distribution }\end{array}$ & $\begin{array}{c}\text { Accumulated even } \\
\text { distribution }\end{array}$ & Difference \\
\hline 5 & 5 & 6.35 & 1.35 \\
\hline 6.5 & 11.5 & 12.7 & 1.2 \\
\hline 6.5 & 18 & 19.05 & 0.9 \\
\hline 6.5 & 24.5 & 25.4 & 0.75 \\
\hline 6.5 & 31 & 31.75 & 0.6 \\
\hline 6.5 & 37.5 & 38.10 & 0.45 \\
\hline 6.5 & 44 & 44.45 & 0.3 \\
\hline 6.5 & 53.5 & 522.25 & 0.15 \\
\hline 6.5 & 50.5 & 57.15 & 0.8 \\
\hline
\end{tabular}

$63.5 / 10=6.35$

Source: own compilation.

Gini $=6.75 / 322.25=0.021$ 
Friedrich L. SELL

Table 2. Calculation of the Gini coefficient for wages ( $€$ per hour), monopoly cum monopsony and competition $(0.5 / 0.5)$ with 10 different markets

\begin{tabular}{|c|c|c|c|}
\hline $\begin{array}{c}\text { Original } \\
\text { Distribution }\end{array}$ & $\begin{array}{c}\text { Accumulated } \\
\text { distribution }\end{array}$ & $\begin{array}{c}\text { Accumulated even } \\
\text { distribution }\end{array}$ & Difference \\
\hline 5 & 5 & 5.75 & 0.75 \\
\hline 5 & 10 & 11.5 & 1.5 \\
\hline 5 & 15 & 17.25 & 2.75 \\
\hline 5 & 20 & 23 & 3 \\
\hline 5 & 25 & 28.75 & 3.75 \\
\hline 6.5 & 31.5 & 34.5 & 3 \\
\hline 6.5 & 38 & 40.25 & 2.75 \\
\hline 6.5 & 44.5 & 46 & 1.5 \\
\hline 6.5 & 51 & 51.75 & 0.75 \\
\hline 6.5 & 57.5 & 57.50 & 0 \\
\hline
\end{tabular}

57.5

297.5

316.25

19.75

$57.5 / 10=5.75$

Source: own compilation.

Gini $=19.75 / 316.25=0.062$

Proposition 1: The Gini coefficient for wages is a positive (negative), monotone function of the degree of monopolisation/monopsonisation (competition) prevailing in the economy. 
CORRECTING INEQUALITY OF PERSONAL INCOMES BEFORE INCOME TAXES ...

Table 3. Calculation of the Gini coefficient for profits ( $€$ per hour), monopoly cum monopsony and competition $(0.1 / 0.9)$ with 10 different markets

\begin{tabular}{|c|c|c|c|}
\hline $\begin{array}{c}\text { Original } \\
\text { Distribution }\end{array}$ & $\begin{array}{l}\text { Accumulated } \\
\text { distribution }\end{array}$ & $\begin{array}{c}\text { Accumulated even } \\
\text { distribution }\end{array}$ & Difference \\
\hline 100 & 100 & 120 & 20 \\
\hline 100 & 200 & 240 & 40 \\
\hline 100 & 300 & 360 & 60 \\
\hline 100 & 400 & 480 & 80 \\
\hline 100 & 500 & 600 & 100 \\
\hline 100 & 600 & 720 & 120 \\
\hline 100 & 700 & 840 & 140 \\
\hline 100 & 800 & 960 & 160 \\
\hline 100 & 900 & 1080 & 180 \\
\hline 300 & 1200 & 1200 & 0 \\
\hline 1200 & 5700 & 6600 & 900 \\
\hline
\end{tabular}

$1200 / 10=120$

Source: own compilation.

Gini $=900 / 6600=0.136$ 
Table 4. Calculation of the Gini coefficient for profits ( $€$ per hour), monopoly cum monopsony and competition $(0.5 / 0.5)$ with 10 different markets

\begin{tabular}{|c|c|c|c|}
\hline $\begin{array}{c}\text { Original } \\
\text { Distribution }\end{array}$ & $\begin{array}{l}\text { Accumulated } \\
\text { distribution }\end{array}$ & $\begin{array}{c}\text { Accumulated even } \\
\text { distribution }\end{array}$ & Difference \\
\hline 100 & 100 & 200 & 100 \\
\hline 100 & 200 & 400 & 200 \\
\hline 100 & 300 & 600 & 300 \\
\hline 100 & 400 & 800 & 400 \\
\hline 100 & 500 & 1000 & 500 \\
\hline 300 & 800 & 1200 & 400 \\
\hline 300 & 1100 & 1400 & 300 \\
\hline 300 & 1400 & 1600 & 200 \\
\hline 300 & 1700 & 1800 & 100 \\
\hline 300 & 2000 & 2000 & 0 \\
\hline 2000 & 1900 & 11000 & 2500 \\
\hline
\end{tabular}

$2000 / 10=200$

Source: own compilation.

Gini $=2500 / 11000=0.227$

Proposition 2: The Gini coefficient for profits per hour is - perfectly in line with the case of wages (see above) - a positive (negative), monotone function of the degree of monopolisation/monopsonisation (competition) prevailing in the economy. 
CORRECTING INEQUALITY OF PERSONAL INCOMES BEFORE INCOME TAXES ...

Table 5a. Calculation of the Gini coefficient for profit income ( $€$ per hour) and wage income ( $€$ per hour) monopoly cum monopsony and competition $(0.1 / 0.9)$ 10 different markets

\begin{tabular}{|c|c|c|c|}
\hline Profit income & Wage income & Total income & $\begin{array}{c}\text { Accumulated } \\
\text { distribution }\end{array}$ \\
\hline 100 & 6.5 & 106.5 & 106.5 \\
\hline 100 & 6.5 & 106.5 & 213 \\
\hline 100 & 6.5 & 106.5 & 319.5 \\
\hline 100 & 6.5 & 106.5 & 426 \\
\hline 100 & 6.5 & 106.5 & 532.5 \\
\hline 100 & 6.5 & 106.5 & 639 \\
\hline 100 & 6.5 & 106.5 & 745.5 \\
\hline 100 & 6.5 & 106.5 & 852 \\
\hline 100 & 6.5 & 106.5 & 958.5 \\
\hline 300 & 5 & 305 & 1263.50 \\
\hline 1200 & 63.5 & 1263.50 & 6056 \\
\hline
\end{tabular}

Source: own compilation. 
Table 5b. Calculation of the Gini coefficient for profit income ( $€$ per hour) plus wage income ( $€$ per hour) monopoly cum monopsony and competition $(0.1 / 0.9)$ 10 markets

\begin{tabular}{|c|c|c|}
\hline Accumulated distribution & $\begin{array}{c}\text { Accumulated even } \\
\text { distribution }\end{array}$ & Difference \\
\hline 106.5 & 126.35 & 19.85 \\
\hline 213 & 252.7 & 39.7 \\
\hline 319.5 & 379.05 & 59.55 \\
\hline 426 & 505.4 & 79.4 \\
\hline 532.5 & 631.75 & 99.25 \\
\hline 639 & 758.1 & 119.1 \\
\hline 745.5 & 884.45 & 138.95 \\
\hline 852 & 1010.8 & 158.8 \\
\hline 958.5 & 1137.15 & 178.65 \\
\hline 1263.50 & 1263.5 & 0 \\
\hline
\end{tabular}

6056.0

6949.25

893.25

Source: own compilation. 
CORRECTING INEQUALITY OF PERSONAL INCOMES BEFORE INCOME TAXES ...

Table 6a. Calculation of the Gini coefficient for profit income ( $€$ per hour) and wage income ( $€$ per hour) monopoly and competition $(0.5 / 0.5)$ with 10 different markets

\begin{tabular}{|c|c|c|c|}
\hline Profit income & Wage income & Total income & $\begin{array}{l}\text { Accumulated } \\
\text { distribution }\end{array}$ \\
\hline 100 & 6.5 & 106.5 & 106.5 \\
\hline 100 & 6.5 & 106.5 & 213 \\
\hline 100 & 6.5 & 106.5 & 319.5 \\
\hline 100 & 6.5 & 106.5 & 426 \\
\hline 100 & 6.5 & 106.5 & 532.5 \\
\hline 300 & 5 & 305 & 837.5 \\
\hline 300 & 5 & 305 & 1142.5 \\
\hline 300 & 5 & 305 & 1447.5 \\
\hline 300 & 5 & 305 & 1752.5 \\
\hline 300 & 5 & 305 & 2057.5 \\
\hline 2000 & 57.5 & 2057.5 & 8835.0 \\
\hline
\end{tabular}

Source: own compilation. 
Table 6b. Calculation of the Gini coefficient for profit income ( $€$ per hour) and wage income ( $€$ per hour) monopoly cum monopsony and competition $(0.5 / 0.5)$ 10 markets

\begin{tabular}{|c|c|c|}
\hline Accumulated distribution & $\begin{array}{c}\text { Accumulated even } \\
\text { distribution }\end{array}$ & Difference \\
\hline 106.5 & 205.75 & 99.25 \\
\hline 213 & 411.5 & 198.5 \\
\hline 319.5 & 617.25 & 297.75 \\
\hline 426 & 823 & 397 \\
\hline 532.5 & 1028,75 & 496.25 \\
\hline 837.5 & 1234.5 & 397 \\
\hline 1142.5 & 1440.25 & 297.75 \\
\hline 1447.5 & 1646.0 & 198.5 \\
\hline 1752.5 & 1851.75 & 99.25 \\
\hline 2057.5 & 2057.5 & 0 \\
\hline
\end{tabular}

8835.0

11316.25

2481.25

Source: own compilation.

Proposition 3: If total income ( $€$ per hour) is the sum of wages ( $€$ per hour) and profits $(€$ per hour), the impact of an increasing degree of monopolisation cum monopsonisation in the economy on the overall Gini coefficient is clear-cut: the higher (lower) the representation of monopolies/monopsonies in the economy is, the higher (lower) will be the associated Gini coefficient. 


\section{Gini decomposition}

Equation (8) is the basic decomposition of the Gini coefficient (ex-ante) following Shorrocks (1982), Doran and Jordan (2016), Costa (2019) and many other contributions.

(8) $G=G_{W}+G_{B}+G_{T}$

$G$ symbols the Gini coefficient of total income for the whole population. $G_{W}$ is obtained quite easily as a weighted sum of the Gini indexes $G_{i}$ of each (say two, 1 and 2, that makes $i=1,2$; in our case the group of wage earners and the group of profit earners) subgroup, where the weights are given by the population (in our case market) share $\mathrm{p}_{\mathrm{i}}$ and the income share $\mathrm{s}_{\mathrm{i}}$ of the two subgroups:

(9) $G_{W}=G_{1} p_{1} s_{1}+G_{2} p_{2} s_{2}$.

"Gw allows to evaluate the contribution to total inequality related to the variability within the subgroups. Low values of $\mathrm{G}_{\mathrm{W}}$ indicate homogenous subgroups ... while a high $\mathrm{G}_{\mathrm{w}}$ provides the opposite indications (Costa 2019: 7). Hence, by definition of (1) and (2), we achieve:

(10) $G-\left(G_{1} p_{1} s_{1}+G_{2} p_{2} s_{2}\right)=G_{B}+G_{T}$,

where in the case of only two subgroups: $\mathrm{p}_{1}=\left(1-\mathrm{p}_{2}\right)$ and $\mathrm{s}_{1}=\left(1-\mathrm{s}_{2}\right) \cdot \mathrm{G}_{\mathrm{B}}$ measures the extent of inequality between subgroups and $G_{T}$ is the overlapping component, which captures the "degree of overlap between the income distributions in the various areas" (Özmucur, Silber 2009: 324):

(11) $G_{B}+G_{T}=G_{12} p_{1} S_{2}+G_{21} p_{2} S_{1}$,

where $G_{12}=G_{21}$ in the case of only two subgroups. So we get:

(12) $G-\left(G_{1} p_{1} s_{1}+G_{2} p_{2} s_{2}\right)=G_{12} p_{1} s_{2}+G_{21} p_{2} s_{1}$,

The term $G_{12}$ or likewise $G_{21}$, when there are only two subgroups, equals the Gini coefficient between group 1 and group 2. According to Costa (2019, S. 9):

(13) $G_{T}=\left(G-G_{W}-\mathrm{p}_{1}-\mathrm{s}_{1}\right) / 2$

A look at Tables 1 through 4 and the respective distribution of wages and profits shows that, in our case, there is no overlapping of the distributions of incomes $\left(G_{T}=0\right)$. Applying hence the above formulas with no over-lapping to our simulation exercise, reveals the following numbers/results: 
(14) $G=G_{1} p_{1} s_{1}+G_{2} p_{2} s_{2}+G_{12} p_{1} s_{2}+G_{2 l} p_{2} s_{1}$,

Table 5b: Income distribution in the mostly competitive economy

From the simulation in the annex, we have: $G=0.129$.

1: wage income; $p_{l}=9 / 10 ; s_{1}=0.05 ; \mathrm{G}_{1}=0.021 ; G_{l} p_{l} s_{l}=0.01$

2: profit income; $p_{2}=1 / 10 ; s_{2}=0.95 ; \mathrm{G}_{2}=0.136 ; G_{2} p_{2} s_{2}=0.013$

(9a) $\mathrm{G}_{\mathrm{W}}=0.01+0.013=0.023$

(10a) $\mathrm{G}-\mathrm{G}_{\mathrm{W}}=0.129-0.023=0.106=\mathrm{G}_{\mathrm{B}}$

Table 6b: Income distribution in the economy with strong market imperfections

From the simulation in the annex, we have: $G=0.219$.

1 : wage income; $p_{l}=5 / 10 ; s_{1}=0.028 ; \mathrm{G}_{1}=0.062 ; G_{l} p_{l} s_{l}=0.001$

2: profit income; $p_{2}=5 / 10 ; s_{2}=0.972 ; \mathrm{G}_{2}=0.227 ; G_{2} p_{2} s_{2}=0.110$

(9a) $\mathrm{G}_{\mathrm{W}}=0.001+0.110=0.111$

(10a) $\mathrm{G}-\mathrm{G}_{\mathrm{W}}=0.219-0.111=0.108=\mathrm{G}_{\mathrm{B}}$

There is a significant difference in the variability within the subgroups: 0.023 vs. 0.111 , where the variability is comparatively higher in the market imperfections scenario of Table $\mathbf{6 b}$. With regard to the inequality between the subgroups, the variability is almost identical, though comparatively smaller in the competitive scenario of Table $\mathbf{5 b}$ (0.106 vs. 0.108).

\section{Competition policy as a device for correcting personal (market) income distribution before income taxes and money transfers do}

It is common knowledge among economists that in a world of ordinary scales, an equal distribution of incomes maximizes total utility, whenever individual marginal utilities of income are identical (Külp 1975: 83). This result changes if individual marginal utilities of income differ (Külp 1975: 85). Now, maximization of total utility requires to render more income to those equipped with the higher marginal utility of income (curve). As the magnitude of individual marginal utilities of income is, in principle, unknown to us, one may think of many types of (more or less) uneven distribution of incomes. As long as we talk about positive economics, 
there is no criterion at hand which helps us to make the best choice. Therefore, we tend to accept the distribution of incomes, as it is delivered by the market process in the first place. If policy makers follow the axioms of a widely respected (normative) welfare function, it is feasible to design an optimal distribution of incomes. However, one may postulate that the market-oriented distribution of incomes itself should not already be biased, long before the government starts to correct it. Put it in these words: the Gini coefficient ex-ante is actually being calculated on the basis of existing significant monopolies and monopsonies, but it should not. An "un-biased" Gini coefficient ex-ante should be computed after correcting for market imperfections. Hence, competition policy has two reasons to fight market imperfections: one is to safeguard a functioning competition on markets and the second is to submit to the policy makers a "well-functioning" income distribution of incomes they may wish to correct afterwards.

Depart from the following thought: the Gini coefficient ex-ante is traditionally higher (see Sell, Öllinger 2019) than the Gini coefficient ex-post (after taxes and transfers installed by policy makers). If competition policy successfully reduces the Gini coefficient ex-ante, the policy effort to reduce the Gini coefficient ex-ante given the envisaged Gini coefficient ex-post - can be lower (and cheaper in terms of the transfer size required), ceteris paribus. In addition, further economic policy chapters, such as minimum wage policy and/or a strategy of wage subsidies, become (more) redundant. Hence, competition policy enhances the efficiency of redistribution (fiscal) and/or of labour market policy.

Moreover, if it becomes less necessary for the government to make use of progressive taxation for the upper income groups, fiscal policy will presumably become more effective as well: because a lower need for redistribution (fiscal) policy reduces the pitfalls of the Laffer curve, too.

In the following, we will assess two options: one is that competition policy eases/enhances the possibilities for new firms to enter monopolized or monopsonized markets, the other is that competition policy makes it harder to monopolies and/or monopsonies to survive under the pressure of taxes, tariffs etc.

The first option has been the subject of a library filling amount of books and articles. Therefore, it seems unnecessary to evoke the key results of these many 
studies. However, we will see below that one can relate specific instruments used by policy makers to directly fight the market power of monopolies and/or monopsonies to the overall goal to create more competition in markets.

Let us inspect the second option. See, for the following (Sell, Kermer 2017: 9093): Fiscal policy has several possibilities to fight monopolies and/or monopsonies and their detrimental effects to consumers (low supply/high prices). The main alternatives consist in taxing profits, taxing revenues or to subsidize costs. Let us begin with the case of a monopoly:

(1) The taxation of profits results primarily in a status-quo: the optimal quantity and the optimal price to the monopolist will not change at all, only his level of profits will be dampened. The consumer rent remains constant. (2) The effects to be expected from a taxation of revenues is even worse for the consumers: The optimal quantity will shrink and the optimal price will rise, hence, the consumer rent is reduced. (3) Economic policy might want to incentivize the monopolist to increase the level of production by granting him a cost subsidy: here, the monopolist will in fact react with an increased supply and a concomitant lowering of the price. The consumer rent, hence, will rise. (4) A fourth option applies to the situation where the domestic (importing) economy faces a foreign (exporting) monopolist. As is the case of (domestic) taxation, one may expect (again only) a rise in the domestic price to consumers, a lowering of the consumer rent and a shrinking supply of goods. One thing, however, can make a difference: if the government deploys the collected tariff revenues in favour of domestic consumers, their loss of consumer rent may be (even more than) compensated. And there might as well exist another indirect effect: profits of the foreign monopolist are reduced. A possible consequence: the domestic market becomes less attractive to the monopolist and he might shift his interest towards other countries.... If so, domestic producers will possibly discover a new market.

What about monopsonies? As can be shown easily, a taxation of profits does, again, not alternate the profit maximum: neither the amount of labour hired nor the wage paid to the employees is affected. Results change quite a bit, when it is not the profit, but the revenue which becomes taxed: The monopsonist will choose for his optimum a lower input of labour, and, accordingly, a lower wage rate offered to the 
employees (see Kermer, Sell 2021, forthcoming). The final option is interesting: paying a (constant) subsidy for any unit produced, will incentivize the monopsonistic firm to increase production and hence employment. Given the upward sloped labour supply function, the wage rate must rise, also. Minimum wages are an interesting case with respect to monopsonies. As we know already from early studies by Card and Krueger (1997), excluding special situations (see Sell, Ruf 2016), minimum wages tend to increase wages and employment offered by the monopsonist. But, there is another "side effect": minimum wages tend to dampen also profits of the monopsonist, what makes this market less attractive for access to further (competing) employers (Sell, Ruf 2016). Hence, the likelihood for a switch in the market from a monopsony to an oligopsony becomes less likely, ceteris paribus. The latter, in turn, would presumably increase the degree of competition. Here comes the link to our first option from above: the specific instruments used against monopolies and analysed earlier, such as the taxation of revenues or profits, the instalment of tariffs to weaken foreign monopolists or the granting of production subsidies, will also be accompanied by "side effects": the effectiveness of these instruments will hence be the higher (lower), the less (more) they are going along with a shrinking profitability of the respective monopoly/monopsony. Ultimately, a kind of trade-off appears: all those instruments designed to "hurt" the monopolist/monopsonist by reducing his net profits, have a countervailing effect on the attractiveness of the market to possible newcomers, as long as its profitability is lowered relatively to the median or the average market in the economy.

\section{Summarizing conclusions}

The aim of this paper was to close the gap between the subjects of personal income distribution on the one hand and of competition policy in markets with (nontransitory and hence non-Schumpeterian) monopolies and monopsonies on the other hand. What have we learnt? First, competition policy has at least two reasons to fight market imperfections: one is to safeguard a functioning competition on markets 
and the second is to submit to the policy makers a "well-functioning" income distribution of incomes they may wish to correct afterwards. Second, competition policy enhances the efficiency of fiscal redistribution and/or of labour market policy. And third: fiscal policy is capable to effectively fight monopolies and monopsonies. The alternative instruments available have been presented above.

As a result, we may summarize that a correction of inequality in personal incomes is feasible ex-ante, that is, long before the government intervenes with taxes and transfers in order to dampen the original Gini coefficient which is the outcome of market processes. In order to put forward our thoughts, we have made use of simple model calibration, simulation and Gini decomposition techniques. A future extension of our approach may search for macro-economically valid indicators for market imperfections which will make an in-depth empirical analysis of this subject possible.

\section{Bibliography}

Apergis N. et al. (2018), Convergence in income inequality. Further evidence from the club clustering methodology across states in the U.S., "International Advances in Economic Research", vol. 24 no. 2, pp. 147-161.

Autor D. et al. (2020), The fall of the labour share and the rise of superstar firms, "Quarterly Journal of Economics", vol. 135 no. 2, pp. 645-709.

Bao Y., Dhongde S. (2009), Testing convergence in income distribution, "Oxford Bulletin of Economics and Statistics", vol. 71 no. 2, pp. 295-302.

Barro R.J., Sala-i-Martin J. (1999), Economic growth, The MIT Press, Cambridge, M.A.

Campano F., Salvatore D. (2006), Income distribution, Oxford Economic Press, Oxford.

Card D., Krueger A.B. (1997), Myth and measurement. The new economics of the minimum wage, Princeton University Press, Princeton.

Castells M. (1996), The information age: economy, society and culture, Blackwell, Chichester, Wiley, Cambridge, M.A.

Chown J. et al. (2019), The opportunities and limitations of monopsony power in healthcare: evidence from the United States and Canada, NBER Working Paper No. 26122, Cambridge, M.A.

Colciago A., Mechelli R. (2020), Competition and inequality, DNB Working Paper No. 689, Netherlands Central Bank, Research Department, Den Haag. 


\section{CORRECTING INEQUALITY OF PERSONAL INCOMES BEFORE INCOME TAXES ...}

Congressional Research (2020), Real Wage trends, 1979-2019. CRS Report, Prepared for Members and Committees of Congress. https://crsreports.congress.gov (19.01.2021)

Costa M. (2019), The evolution of gender income inequality by means of the Gini index decomposition, Working Paper DS No. 1130, Universita di Bologna.

Cowell F.A., Mehta F. (1982), The estimation and interpolation of inequality measures, "The Review of Economic Studies", vol. 49, pp. 273-290.

Desilver D. (2018), For most Americans, real wages have barely budged for decades, PEW Research Center, August 7, https://www.pewresearch.org/fact-tank/2018/08/07/for-most-us-workers-real-wageshave-barely-budged-for-decades/ [08.06.2021].

Doran J., Jordan D. (2016), Decomposing US regional income inequality from 1969 to 2009, “Applied Economics Letters", vol. 23 no. 10-12, pp. 781-784.

Doran J., Jordan D. (2020), The wolf at the door. The menace of economic insecurity and how to fight it, Harvard University Press, Cambridge, M.A.

Frank M.W. (2021), U.S. state-level income inequality data, https://www.shsu.edu/eco $\neg$ mwf/inequality.html [17.01.2021].

Goolsbee A., Syverson C. (2019), Monopsony power in higher education: a tale of two tracks, NBER Working Paper No. 26070, Cambridge, M.A.

Guo Y., Sell F.L. (2020), Equilibrium and convergence in personal income distribution? How European countries performed during a phase of huge economic turbulence (2004-2017), Working Papers in Economics, vol. 31, no. 1, Neubiberg.

Guo Y., Sell F.L. (2021), Equilibrium and convergence in income distribution. The case of 28 European countries in the recent, turbulent past (1995-2019), "Central European Economic Journal", vol. 8 , no. 55 , forthcoming.

Hefti A., Teichgräber J. (2021), Inequality in models with a competition for market shares, Universität Zürich, Institut für Volkswirtschaftslehre, Working Paper No. 375, Zurich.

Helble M. et al. (2018), The impact of increased import competition from the People's Republic of China on income inequality and household welfare in Vietnam, Asian Development Bank Institute. Working Paper No. 864, Tokyo.

Külp B. (1975), Wohlfahrts-Ökonomik I: Die Wohlfahrtskriterien, J.C.B. Mohr, Werner-Verlag, Tübingen.

Lin P.-C., Huang H.-C. (2012), Convergence in income inequality? Evidence from panel unit root tests with structural breaks, "Empirical Economics", vol. 43, pp. 153-174.

Makofske M. (2018), Are you hiring Johnny Football or Johnny Doe? Uncertain labour quality and measurement of monopsony in college football, "Applied Economics", vol. 50 no 22, pp. 2415-2430. 
McKinsey \& Company (2019), A new look at the declining labour share of income in the United States. Discussion Paper, May 22, https://www.mckinsey.com/featured-insights/employment-andgrowth/ [15.01.2021].

Moore M., Tambini D. (2018), Digital dominance. The power of Google, Amazon, Facebook, and Apple, Oxford University Press, Oxford.

Motta M. (2009), Competition policy: theory and practice, 9th ed., Cambridge University Press, Cambridge.

Öllinger M., Sell F.L. (2017), What determines unions' density? A political economy model of the labour market with empirical evidence in the context of European countries, "Review of Economics and Finance", vol. 10 no. 4, pp. 18-32.

Oezmucur S., Silber J. (2008), Internal migration, household size and income inequality in Turkey, in: Advances on income inequality and concentration measures, Betti G., Lemmi A. (eds.), Routledge, London, New York, pp. 324-339.

Ostermair C., Sell F.L. (2020), Are minimum wages an appropriate lever to restore the wage share?, unpublished work, Neubiberg.

Piketty T., Saez E. (2003), Income inequality in the US, "Quarterly Journal of Economics", vol. 118, pp. 1-39.

Rey S.J. (2018), Bells in space. The spatial dynamics of US interpersonal and interregional income inequality, "International Regional Science Review”, vol. 41 no. 2, pp. 152-182.

Richter F. (2019), Average hourly wages climb to unprecedented high, June 13, https://www.statista.com/ [25.05.2021].

Sell F.L. (2015), The new economics of income distribution. introducing equilibrium concepts into a contested field, Edward Elgar Publishing, Cheltenham.

Sell F.L., Kermer S. (2017), Aufgaben und Lösungen in der Volkswirtschaftslehre. Arbeitsbuch zu Engelkamp, 4th ed., Springer Verlag, Berlin, Heidelberg, New York.

Sell F.L., Kermer S. (2021), Aufgaben und Lösungen in der Volkswirtschaftslehre. Arbeitsbuch zu Engelkamp, 5th ed. Springer Verlag, Berlin, Heidelberg, New York, forthcoming.

Sell F.L., Ruf E.K. (2016), Monopsony in the labour market, minimum wages and the time horizon: some unresolved issues, "Atlantic Economic Journal”, vol. 44 no. 1, pp. 75-90.

Shira J. (2003), Statistische Methoden der VWL und BWL. Theorie und Praxis, Pearson Studium, München, Boston, San Francisco.

Shorrocks A.F. (1982), Inequality decomposition by factor components, "Econometrica", vol. 50 no. 1, pp. 193-211.

Stricker F. (2020), American unemployment. Past, present, and future, University of Illinois Press, Urbana. 